\title{
Saharan dust and ice nuclei over Central Europe
}

\author{
H. Klein ${ }^{1}$, S. Nickovic ${ }^{2}$, W. Haunold ${ }^{1}$, U. Bundke ${ }^{1}$, B. Nillius ${ }^{1}$, M. Ebert ${ }^{3}$, S. Weinbruch ${ }^{3}$, L. Schuetz ${ }^{4}$, Z. Levin ${ }^{5}$, \\ L. A. Barrie ${ }^{2}$, and H. Bingemer ${ }^{1}$ \\ ${ }^{1}$ Institute for Atmospheric and Environmental Sciences, Goethe-University, Frankfurt am Main, Germany \\ ${ }^{2}$ World Meteorological Organization, Geneva, Switzerland \\ ${ }^{3}$ Institute for Applied Geosciences, Technical University of Darmstadt, Germany \\ ${ }^{4}$ Institute for Atmospheric Physics, Gutenberg-University, Mainz, Germany \\ ${ }^{5}$ Deptartment of Geophysics, Tel Aviv University, Tel Aviv, Israel
}

Received: 19 May 2010 - Published in Atmos. Chem. Phys. Discuss.: 21 June 2010

Revised: 11 October 2010 - Accepted: 13 October 2010 - Published: 1 November 2010

\begin{abstract}
Surface measurements of aerosol and ice nuclei (IN) at a Central European mountain site during an episode of dust transport from the Sahara are presented. Ice nuclei were sampled by electrostatic precipitation on silicon wafers and were analyzed in an isothermal static vapor diffusion chamber. The transport of mineral dust is simulated by the Eulerian regional dust model DREAM. Ice nuclei and mineral dust are significantly correlated, in particular IN number concentration and aerosol surface area. The ice nucleating characteristics of the aerosol as analyzed with respect to temperature and supersaturation are similar during the dust episode than during the course of the year. This suggests that dust may be a main constituent of ice nucleating aerosols in Central Europe.
\end{abstract}

\section{Introduction}

In this paper we present surface measurements of atmospheric ice nuclei (IN) in Central Europe together with dust transport modeling of an episode in May 2008, when Saharan dust was transported over a distance of $2500 \mathrm{~km}$ northward across the European continent.

Mineral dust aerosols that are suspended in the atmosphere during dust storms are spread over a wide geographic range of the Northern Hemisphere (Prospero, 1999; Kaufmann et al., 2002; Sassen, 2002; Sassen et al., 2003). Dust aerosols directly affect the radiative balance of the earth-atmosphere system through scattering and absorption, changing the atmospheric dynamics and temperature profiles during major

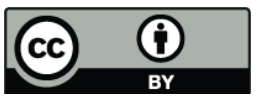

Correspondence to: $\mathrm{H}$. Klein (holger.klein@iau.uni-frankfurt.de) dust storms (Nickovic, 2005; Pérez et al., 2006). Furthermore, their cloud-active fraction modifies the size distribution and the phase of cloud particles by acting as cloud condensation nuclei $(\mathrm{CCN})$ and as ice nuclei. This may in turn affect indirectly the atmospheric radiative balance and thus weather and climate (IPCC, 2007; Zeng et al., 2009), as well as the development of precipitation (Levin and Cotton, 2009). Mineral dust particles are particularly known to act as efficient heterogeneous ice nuclei (Pruppacher and Klett, 1997; Field et al., 2006; Knopf and Koop, 2006; Zimmermann et al., 2008; Niedermeier et al., 2010; Murray et al., 2010). The effect of desert dust on the glaciation of clouds has been reported from lidar backscattering and depolarization measurements. For instance, Sassen (2002) observed that the occurrence of dust from Asian sources over the western United States coincided with unusually warm cirrus layers (about $20^{\circ} \mathrm{C}$ warmer than normal). These ice clouds were presumably produced by the dust-induced glaciation of supercooled liquid altocumulus. Similar observations were reported for Saharan dust events over southern Florida (Sassen et al., 2003) and over central Europe (Ansmann et al., 2005). However the coexistence of dust and supercooled droplets does not necessarily result in immediate glaciation. From their measurements in southern Morocco, Ansmann et al. (2008) conclude that ice formation is a strong function of cloud temperature and does not occur above $-20^{\circ} \mathrm{C}$. Recently Wiacek et al. (2010) explored the availability of mineral dust particles as ice nuclei for interactions with clouds by analyzing the thermodynamic conditions (temperature and humidity) for the formation of liquid, mixed-phase and ice clouds along of 1.8 million trajectories from the major African and Asian dust source areas over a whole year. Of those trajectories that encountered conditions for cloud formation by far the largest fraction entered conditions of mixed-phase

Published by Copernicus Publications on behalf of the European Geosciences Union. 
clouds, where mineral dust can initiate glaciation. Space observations (Choi et al., 2010) show that on the planetary scale the fraction of supercooled clouds $\left(\right.$ at $-20^{\circ} \mathrm{C}$ ) and the coincident dust aerosol frequency are negatively correlated, likely due to glaciations by dust.

Although ice nuclei are a necessary ingredient for the glaciation of tropospheric mixed-phase clouds and for the formation of precipitation via the Bergeron-Findeisenprocess, their atmospheric concentration is rarely measured. From measurements in Japan Isono et al. (1959) concluded that the deserts of continental Asia are main sources of ice nuclei over Japan, and Hobbs et al. (1971) have shown by measurements at Hawaii, Alaska and Washington State that ice nuclei can be transported across the north Pacific Ocean over thousands of kilometers. Sassen et al. (2003) and DeMott et al. (2003a) report measurements of ice nuclei number concentration, using the Colorado State University's continuous flow diffusion chamber (CFDC). In African dust plumes at $1-4 \mathrm{~km}$ altitude over Florida extraordinarily high ice nucleus number concentrations of up to $10^{3} \mathrm{~L}^{-1}$ at $-36.5^{\circ} \mathrm{C}$ were observed. From 14 years of field studies with the CFDC DeMott et al. (2010) derived a parameterization of the IN number concentration as a function of the number of particles larger than $0.5 \mu \mathrm{m}$ diameter and temperature. Recently Prenni et al. (2009) reported that ice nuclei sampled in the Central Amazon Basin were primarily composed of carbonaceous material of local biogenic origin and of dust from the Sahara.

Bertrand et al. (1973) found that the ice nuclei concentration (measured at $-20^{\circ} \mathrm{C}$ ) at Abidjan, Ivory Coast, increased from $10 \mathrm{~L}^{-1}$ to around $40-50 \mathrm{~L}^{-1}$ during advection of Saharan dust particles in Harmattan air masses.

Dust fall and red rains due to long range transport of Saharan dust into Central Europe has been reported in the literature since the 19th century (Ehrenberg, 1849). Ice core samples from non-temperate glaciers in the summits of the Alps show annual layers with reddish-yellow Saharan dust deposits ranging over many centuries into historical times (Tomadin et al., 1996). This transport phenomenon frequently takes place when subtropical air masses are advected from Northern Africa. Over the whole Sahara, a quasipermanent reservoir of airborne dust can be observed. This reservoir is continuously supplied with dust generated by high surface winds in synoptic-scale extratropical surface depressions, meso-scale density currents related to convection over the mountain regions, small-scale dry convective mixing in the planetary boundary layer, and small-scale disturbances (Schepanski et al 2007; Knippertz et al., 2009).

The long range transport of African dust into Europe is well documented. Measurements made by an Aerosol Lidar and a multi filter rotating shadowband radiometer in the period 1999-2008 at Lampedusa (Di Iorio et al., 2009) show the evolution of the aerosol vertical distribution in the Central Mediterranean Sea. Dust layers are present in the profile in $38 \%$ of the cases throughout the year, and in $57 \%$ in sum- mer. The highest altitude of dust layers is observed in late spring, up to $9 \mathrm{~km}$ altitude dust is then available for transport into northerly directions under suitable meteorological conditions (Barkan et al., 2004). From systematic observations made by the European Aerosol Research Lidar Network (EARLINET) during the period May 2000 to December 2002 Papayannis et al. (2008) found that the number of dust events was greatest in late spring, summer, and early autumn periods, mainly in southern, southeastern, and south-central Europe. Multiple aerosol dust layers of variable thickness (300$7500 \mathrm{~m}$ ) were observed. In less frequent cases dust reached northwestern, northern, or northeastern Europe. The systematic occurrence of Saharan dust events is well documented over a period of many years at the high Alpine Jungfraujoch observatory by Collaud Coen et al. (2004), based on time series of scattering and absorption coefficient measurements. A climatology of dust event observations north of the Alps has been established at the WMO global observatory Hohenpeissenberg in southern Germany (Kaminski, 2006). It shows that on average one dust event that produces visible dust deposits or optical phenomena occurs each month throughout the year and even more minor events are recorded. Raman Lidar measurements (Mattis et al., 2008) at Leipzig, Germany, over the past 10 years in the framework of the German Lidar Network (1997-2000) reveal a frequency distribution of Sahara dust events peaking in late spring and during fall, which can be taken as representative for central Europe and also for the Taunus Observatory site.

\section{Methods}

\subsection{Measurements of ice nuclei and of aerosol physical properties}

The number concentration of ice nuclei was measured since April 2008 on a regular daily basis at the Taunus Observatory of the Goethe-University on Mt. Kleiner Feldberg, a low mountain range ( $825 \mathrm{~m}$ a.s.l.; $50^{\circ} 13^{\prime} \mathrm{N}, 8^{\circ} 27^{\prime} \mathrm{E}$ ) in central Germany, approximately $25 \mathrm{~km}$ north of the city of Frankfurt am Main. This paper is focussed on ice nucleus observations in May/June 2008 during the strongest event of Saharan dust advection to Germany since five years, based on the record of total suspended particulates at Hohenpeissenberg (H. Flentje, German Meteorological Service DWD, personal communication, 2010). The entire ice nuclei record is presented and analyzed in a separate paper (Klein et al., 2010a).

For the measurement of the ice nuclei number concentration, atmospheric aerosol was first collected on an inert substrate, which was later analyzed in the laboratory for ice nuclei. Samples were collected from a platform on the roof of the Atmospheric Physics Laboratory at hilltop. The air inlet was at $8 \mathrm{~m}$ above ground. A main flow of $601 \mathrm{~min}^{-1}$ of ambient air was pumped through a Sigma-2 inlet (VDI 1997) and a $25 \mathrm{~mm}$ I.D $\times 4 \mathrm{~m}$ length glass tube into the laboratory. 
The $50 \%$ cutoff diameter of this inlet system as calculated by FLUENT 3-D for $5 \mathrm{~m} \mathrm{~s}^{-1}$ wind speed is $23 \mu \mathrm{m}$. Ice nuclei samples as well as samples for aerosol physical measurement in the $10 \mathrm{~nm}-20 \mu \mathrm{m}$ size range were collected isokinetically from the main sample flow, using the pumps of the individual instruments together with appropriate inlet nozzles. The total aerosol number concentration was measured by a TSI 3785 Condensation Particle Counter (CPC). Aerosol size spectra were measured by a TSI 3936 Scanning Mobility Particle Sizer (SMPS) in the $10 \mathrm{~nm}-414 \mathrm{~nm}$ diameter range and by a TSI 3321 Aerodynamic Particle Sizer (APS) from $523 \mathrm{~nm}-20 \mu \mathrm{m}$ diameter. Spectra of particle number concentration were converted from aerodynamic diameter $d_{a}$ measured by APS to volume equivalent diameter $d_{\mathrm{e}}$ by using the relation $d_{\mathrm{a}}=d_{\mathrm{e}}\left(\rho_{p} / \rho_{0} \chi\right)^{1 / 2}$ (Hinds 1998), with $\rho_{0}=1 \mathrm{~g} \mathrm{~cm}^{-3}, \chi=$ dynamic shape factor, $\rho_{p}=$ particle density. From these spectra the particle mass spectra and mass concentration were derived. A dynamic shape factor of $\chi=1.5$ and a particle density of $\rho_{p}=2.6 \mathrm{~g} \mathrm{~cm}^{-3}$ were assumed (Tegen and Fung, 1994, Kandler et al., 2007). For comparison to other measurements we consider below from our APS measurements only the mass of particles smaller than $d_{\mathrm{pe}}=10 \mu \mathrm{m}$, for which we use the term $\mathrm{PM}_{10}$. On average $98.5 \%$ of the particle mass is measured below $10 \mu \mathrm{m} d_{p}$.

For the sampling of ice nuclei, 101 of air were pumped at $21 \mathrm{~min}^{-1}$ through an electrostatic precipitator, which deposits aerosol particles on the surface of $47 \mathrm{~mm} \varnothing$ silicon wafers (Klein et al., 2010). These samples were then subsequently analyzed at specified temperatures and supersaturations in the isothermal static diffusion chamber FRIDGE (Bundke et al., 2008; Klein et al., 2010) for their ice nuclei number. Each sample was analyzed at the following sequence of temperatures (and supersaturations with respect to ice $\left.\left(\mathrm{RH}_{\mathrm{ICE}}\right)\right):-8^{\circ} \mathrm{C}(103 \%, 105 \%, 107 \%) ;-13^{\circ} \mathrm{C}(106 \%$, $110 \%, 113 \%)$, and $-18^{\circ} \mathrm{C}(110 \%, 115 \%, 119 \%)$. Ice crystals grown on the nuclei by deposition and condensation freezing were viewed by a CCD camera, and counted automatically. The precision derived from multiple sampling and analysis of test aerosol is $9 \%$. The procedure was described in detail by Klein et al. (2010). Samples were usually analyzed within 24 hours. Ice nucleus concentrations reported here will refer to $-18{ }^{\circ} \mathrm{C}$ and $\mathrm{RH}_{\mathrm{ICE}}=119 \%$, unless stated otherwise. After activation and counting of the ice nucleus samples by FRIDGE some of the samples were transferred to an Environmental Scanning Electron Microscope (ESEM) at University of Darmstadt. The elemental composition of individual particles found at those coordinates on the substrate where ice nucleation was observed in the images by FRIDGE, was measured by energy-dispersive X-ray microanalysis (EDX). The unambiguous identification of the analyzed particles as ice nuclei was enabled by a high precision laser engraved coordinate system on the substrates. The positions on the substrates, where ice nucleation was observed by the CCD camera of FRIDGE, can be recovered in the ESEM with a lateral resolution of approximately $5 \mu \mathrm{m}$.
In addition a variety of meteorological parameters from the weather station of the German Meteorological Service DWD and of air pollution data are also available at the site.

\subsection{Modeling the dust transport}

The DREAM dust model (Nickovic et al., 2001; Nickovic, 2002) was used to study the temporal and spatial evolution of the dust transport event. It is a regional model designed to simulate and/or predict the atmospheric flow of mineral dust aerosol. It solves the Euler-type equation for dust mass continuity. Eight size bins covering the particle diameters from 0.2 to $20 \mu \mathrm{m}$ (Table 1) are used to describe the size distribution of dust (Pérez et al., 2006). Model data presented below are the cumulative mass of particle bins 1-7 called here $\mathrm{PM}_{10}^{\text {model }}$. DREAM is driven by the atmospheric NCEP/Eta atmospheric model. The mass concentration equation simulates all major components of the atmospheric dust cycle such as dust emission from sources, vertical and horizontal mixing and advection, and dry and wet deposition. Wind erosion of the soil in the DREAM parameterization scheme is controlled by the type of soil (soil texture), type of vegetation cover, soil moisture content, and surface atmospheric turbulence. Dust emission originates from model computational points recognized as dust productive soils. Such dust source points are defined according to the USGS global $1 \mathrm{~km}$ land cover data. Different from most other dust models, DREAM includes a viscous sub-layer between the surface and the lowest model layer (Janjic, 1994) in order to regulate dust emission as a function of the near-surface turbulence intensity. The model parameterizes the dry particle deposition (Georgi, 1986) taking into account dependence of deposition on turbulent and Brownian diffusion, gravitational settlement, and interception and impaction on surface roughness objects. The wet deposition parameterization is based on a simple below-cloud scavenging by precipitation. The simulation experiment in this study was performed by running the model in one-day sequences, in which new initial atmospheric conditions from a global model analysis were updated every day and boundary values of model variables were specified every six hours. Since there are not yet satisfactory three-dimensional dust concentration observations to be assimilated, the dust concentration field was initialized every day using 24-h dust forecasts from a previous day. Only in the "cold start" of the model on 18 May 2008 is the concentration set to zero permitting the model several days before the dust event started to spin-up the concentration. The model resolution is set to $50 \mathrm{~km}$ in the horizontal and to 24 layers extending up to approximately $16 \mathrm{~km}$ in the vertical and approximately 3 model layers in the planetary boundary layer. The exceptionally large south to north extent of the dust event dictated the use of a rather large model domain ranging from the Saharan sources to the Scandinavian Peninsula. 
Table 1. Dust size bins introduced in the model. $d_{\min }$ and $d_{\max }$ are minimum and maximum diameter and $d_{\mathrm{eff}}$ is effective diameter for each size bin.

\begin{tabular}{ccc}
\hline Bin number & $d_{\min }-d_{\max }, \mu \mathrm{m}$ & $d_{\mathrm{eff}}, \mu \mathrm{m}$ \\
\hline 1 & $0.2-0.36$ & 0.3 \\
2 & $0.36-0.6$ & 0.50 \\
3 & $0.6-1.2$ & 0.90 \\
4 & $1.2-2$ & 1.56 \\
5 & $2-3.6$ & 2.6 \\
6 & $3.6-6$ & 4.4 \\
7 & $6-12$ & 7.6 \\
8 & $12-20$ & 14.2 \\
\hline
\end{tabular}

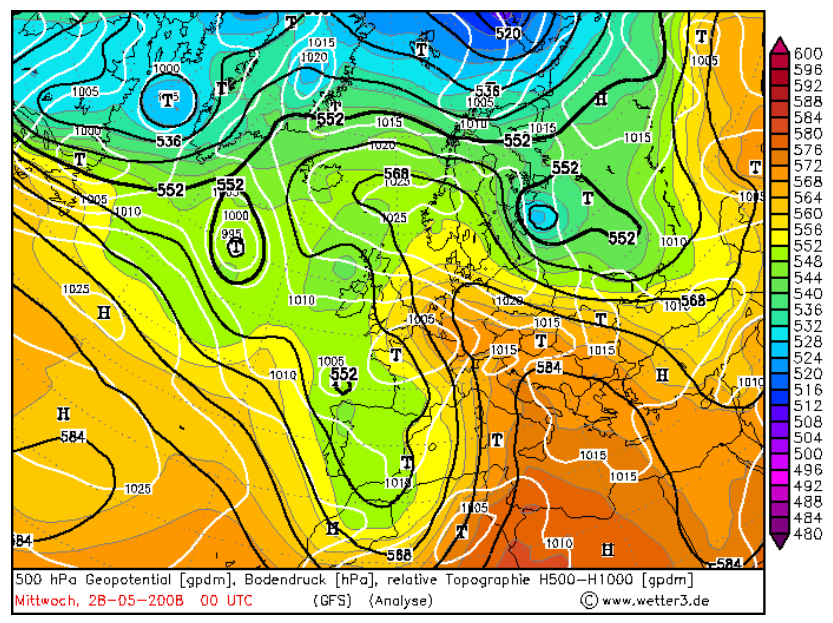

Fig. 1. $500 / 1000 \mathrm{hPa}$ relative topography and surface pressure on 28 May 2008.

\section{Results}

\subsection{The Sahara dust episode of May 2008}

During 22-30 May 2008 the $500 \mathrm{hPa}$ pressure pattern over the Northeast Atlantic (Fig. 1) was dominated by a persistent low at about $1000 \mathrm{~km}$ south of Iceland, with a trough directed southeast towards the Iberian Peninsula and Morocco. Along the eastern side of the trough a strong southerly flow from the western and central Sahara across the Mediterranean Sea towards Central Europe prevailed. METEOSAT data indicate that the Western Sahara dust source regions were active during 30-40\% of the time in May 2008 (I. Tegen, personal communication, 2009). Strong southerly winds through the entire troposphere $\left(40 \mathrm{~m} \mathrm{~s}^{-1}\right.$ at $600 \mathrm{hPa}$ on 28 May) advected dust layers between 27 and 31 May, as indicated by the backtrajectories calculated by the German Meteorological Service DWD (Fig. 2). For 26-28 May the trajectories point to dust sources in the central northern Sahara (northeastern Algeria, Tunisia, and Libya). The trajectory of 29 May extends to northern Mauritania. This area northwest of Tim-
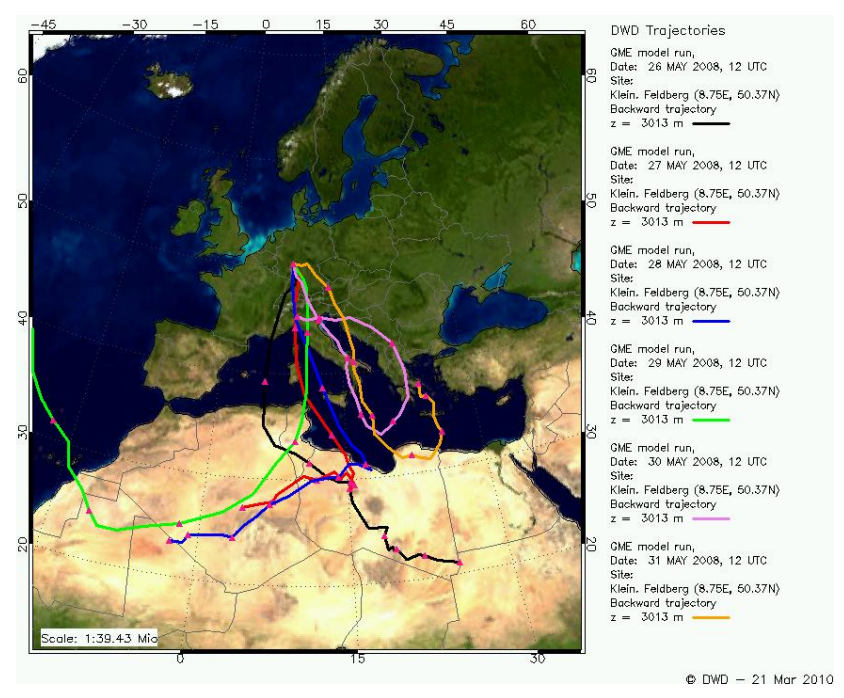

Fig. 2. Backward trajectories arriving at the Taunus Observatory during 26-31 May 2008, calculated by the German Meteorological Service (DWD).

buktu is described as one of the most intense dust sources throughout the year (Prospero et al., 2002) The evolution of the spatial distribution of total column mineral dust during the event as modeled by DREAM (Fig. 3) shows a large scale meandering plume of dust, spreading from the Algerian/Libyan Sahara far northward across Europe to Scandinavia and the Norwegian Sea. The concentration field valid for 12:00 UTC 29 May displayed in the north-south vertical transect $\left(10^{\circ} \mathrm{E} ; 40-63^{\circ} \mathrm{N}\right)$ shows that the concentration travels at rather high elevations, in some regions reaching $10 \mathrm{~km}$ (Fig. 4). One may also notice spatially distributed concentration pulses, that generate temporal pulses visible in the ground-based measurements and model simulation results (see also Fig. 7).

Shallow low pressure systems over the western Mediterranean and Central Europe frequently caused clouds and precipitation along the transport path, but did not prevent the transport of significant amounts of dust across the Alps to central and northern Europe. Surface measurements of $\mathrm{PM}_{10}$ of the German Federal and Regional air pollution monitoring networks (Fig. 5a) exceeded the European legal limits for 24 hour exposure $\left(50 \mu \mathrm{g} \mathrm{m}^{-3}\right)$ over wide areas of southern and western Germany during the days of maximum dust advection on 28-30 May (Umweltbundesamt 2008). The surface distribution of $\mathrm{PM}_{10}^{\text {model }}$ over Germany modeled by DREAM (Fig. 5b) closely resembles the measured structures and concentration levels (Fig. 5a), as can be seen for the $24 \mathrm{~h}$ means of 29 May. The plume axis is running from the southeast to the central west. In the model the maximum is somewhat shifted towards southwest as compared to the measurements. Both the peak levels of around $100 \mathrm{\mu g} \mathrm{m}^{-3}$ measured in the south and the $50-100 \mu \mathrm{g} \mathrm{m}^{-3}$ areas in the central west of the network are well reproduced by the model. 

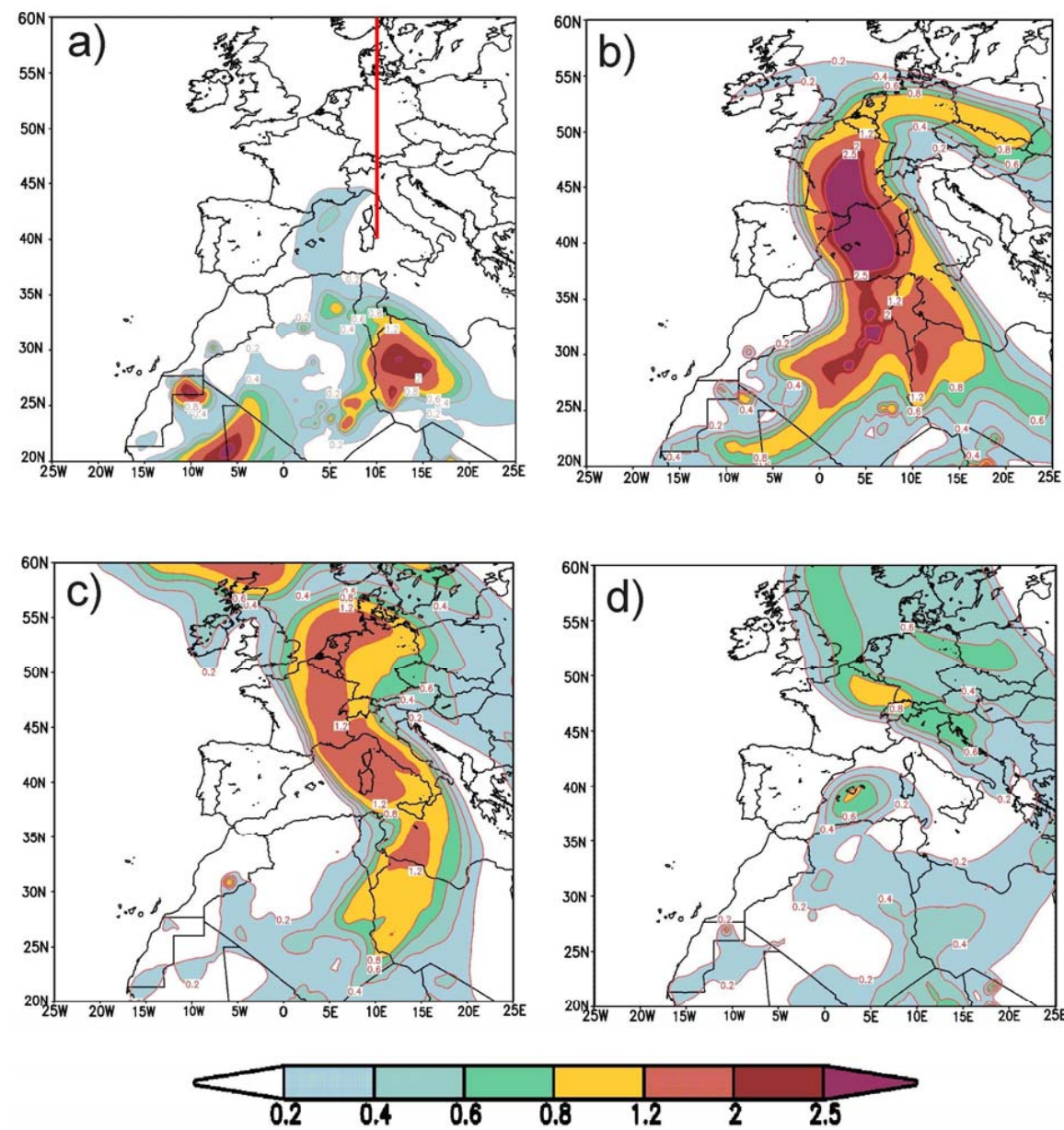

Fig. 3. Total vertical column dust load (vertically integrated concentration in $\mu \mathrm{g} / \mathrm{m}^{2}$ ) during the dust event as simulated by the DREAM model for 12 GMT on May 25 (a), 27 (b), 29 (c), and 31 (d). The red line at $10^{\circ} \mathrm{E}$ in panel (a) indicates the position of the vertical panel along which the concentration is plotted in Fig. 4.

Next, we discuss the event as seen from the Taunus Observatory. Figure 6 compares the mean size distributions of particle number and mass that were measured by APS and SMPS before, during, and after the passage of the dust plume. As expected the dust plume increased predominantly the number and mass of particles that are larger than $0.5 \mu \mathrm{m}$ in diameter. The modelled (squares in Fig. 6) and measured size spectra for the dust period compare well. Figure 7 shows the evolution of $\mathrm{PM}_{10}$ and $\mathrm{PM}_{10}^{\text {model }}$ at the Taunus Observatory as a function of time. In addition it shows the $\mathrm{PM}_{10}$ concentration measured at Wasserkuppe (HLUG 2008), an air pollution monitoring station at $950 \mathrm{~m}$ altitude on top of a mountain $110 \mathrm{~km}$ northeast of the Observatory. Some of the $15-25 \mu \mathrm{g} \mathrm{m}^{-3}$ positive offset of $\mathrm{PM}_{10}$ against $\mathrm{PM}_{10}^{\text {model }}$ during May 24-26 could be due to pollution (sulfate, nitrate, soot, organics, etc.) that is not covered in the dust model. The mean $\mathrm{PM}_{10}$ concentration in this area in May is $20 \mathrm{\mu g} \mathrm{m}^{-3}$ (HLUG 2008a). Both $\mathrm{PM}_{10}^{\text {model }}$ and $\mathrm{PM}_{10}$ start to rise simultaneously in the early morn- ing hours of 27 May and undergo a series of five individual peaks until 31st of May (labeled \#1-5 in Fig. 7). Pulses with approximately the same frequency exists also in the observed AERONET coarse mode aerosol optical depth signal (http://aeronet.gsfc.nasa.gov) at Leipzig, $300 \mathrm{~km}$ eastward of Taunus Observatory (not shown). While the measured and modeled peaks in all three data sets coincide well in time, the peaks \#2 and \#3 are overestimated by model, whereas peaks \#4 and \#5 agree well between measurement and model. We believe that these discrepancies mainly result from subscale phenomena that occur on these days and are not represented in the model, namely thunderstorm development, in particular orographically enforced convection over the Taunus hills. Radar echoes show the development of moderate convective precipitation over the Taunus in the afternoon of 28 (peak \#2) and 29 May (peak \#3), and the northward passage of two large cumulonimbus clusters over the Taunus ridge at 00:0005:00 $\mathrm{h}$, and at 19:00-22:00 $\mathrm{h}$ local time on 30 May. 


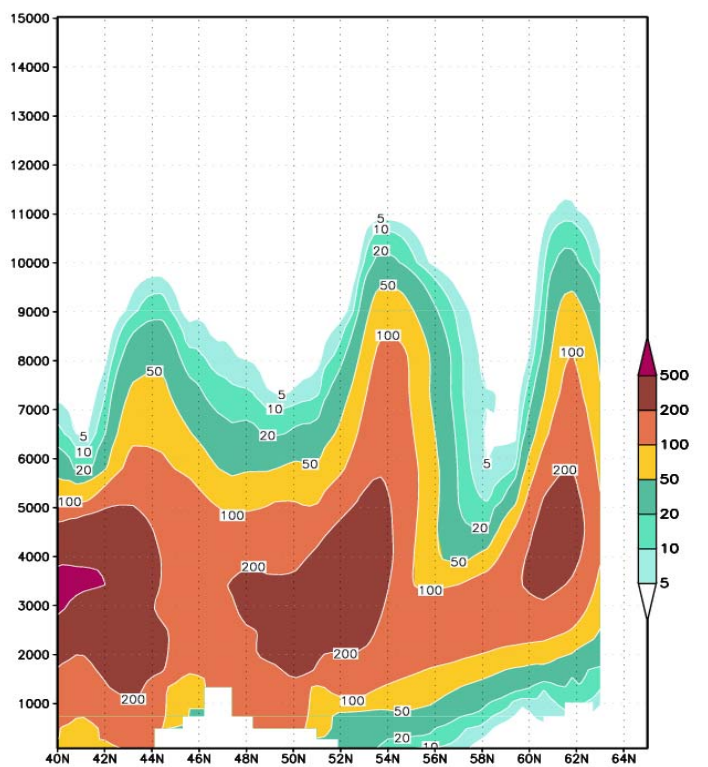

Fig. 4. North-south vertical transect of the mineral dust concentration $\left(\mathrm{PM}_{10}^{\text {model }}\right)$ at $10^{\circ} \mathrm{E}$ on 29 May 2008 (12:00 UTC) as modeled by DREAM. The geographical position is marked by the red line in Fig. 3a.

\subsection{Ice nuclei observations}

The ice nuclei number concentration (at $-18^{\circ} \mathrm{C}$ ) at the Taunus Observatory during the dust event (Fig. 8) is significantly higher than our monthly mean value of $40 \mathrm{INL}^{-1}$ for May 2008 and 2009. Peaks of up to $200-312 \mathrm{IN} \mathrm{L}^{-1}$ were recorded on 29, 30, and 31 May. Several features point to mineral dust as a dominant contributor to the IN. First, the record of IN (Fig. 8) parallels the records of $\mathrm{PM}_{10}^{\text {model }}$ and of $\mathrm{PM}_{10}$ (Fig. 7) in surprisingly many details. $\mathrm{PM}_{10}^{\text {model }}$ shows five distinct maxima, the three largest of which are matched by IN peaks. IN are significantly correlated to the $\mathrm{PM}_{10}^{\text {model }}$ ( $R=0.888, n=8)$, but less to $\mathrm{PM}_{10}$ derived from the measurements (Table 2). Most likely the relation between IN and $\mathrm{PM}_{10}$ is obscured by the presence of $\mathrm{PM}_{10}$ constituents like soot, acids, sea salt and others that have a poor or even adverse effect on the nucleating ability of the aerosol. IN is also highly correlated to the particle mass in the each of the size bins between $1.2 \mu \mathrm{m}$ and $12 \mu \mathrm{m}$ (bins $4-7$ ) both for the APS measurements $(R=0.822, n=15)$, and the model data ( $R=0.838, n=7$ ). This size range covers the typical mass median diameters of $1-3 \mu \mathrm{m}$, which are reported for mineral dust after long range transport (Duce 1995; Prospero 1999, and references therein).
Table 2. Linear Correlation coefficients between ice nuclei number concentration (\#/l) and measured or modelled (spectral) aerosol properties. The $\mathrm{PM}_{10}^{\text {model }}$ data for the correlation analysis were linearly interpolated for the time of aerosol sampling (usually 2/day) within the $3 \mathrm{~h}$ time step in the model output. The IN data used for correlation analysis were (a) the means of daily pairs of samples (triangles in the insets of Fig. 8, n=7) for correlation to model data, and (b) all individual data points of the period May 24 through June 1 (diamonds, $n=15$ ) for correlation to measurement data.

\begin{tabular}{lll}
\hline Parameter correlated to IN & Model & Measurement \\
\hline PM $_{10}$ & $R=0.888, n=7$ & $R=0.609, n=15$ \\
$\begin{array}{l}\text { particle surface of bins 1-7 } \\
\text { Mass in size bins 4-7 }\end{array}$ & $R=0.919, n=7$ & $R=0.370, n=15$ \\
Surface, bin 2 of model & $R=0.938, n=7$ & $R=0.822, n=15$ \\
Surface, bin 4 of measurement & & \\
\hline
\end{tabular}

Second, the IN number is significantly correlated to the aerosol surface, in particular in those size regimes that are dominated by mineral dust. Heterogeneous nucleation is viewed as a surface phenomenon, with the number of IN being related to the particle surface area and probability of occurrence of active sites per unit area of the nucleating material (Pruppacher and Klett, 1997; Phillips et al., 2008). High correlations of IN are found to the modelled total particle surface area of bins $1-7(R=0.919, n=7, \alpha<0.01$; Fig. 8), and to surface in each of the size bins. The correlation of IN to the APS-derived particle surface is low for the total surface area of bins $1-7(R=0.370, n=15)$ and the size bins below $1.2 \mu \mathrm{m}$, but higher in the size range of $1.2-12.0 \mu \mathrm{m}$, with a maximum $(R=0.846, n=15, \alpha<0.001)$ at $1.2-2 \mu \mathrm{m}$. From our data of 27 May through 1 June 2008, we calculate a mean ( \pm standard error of the mean, $n=12$ ) ratio $\xi$ of activated IN to the surface area of $0.5-20 \mu \mathrm{m}$ diameter particles (derived from APS measurements) of $1.08 \times 10^{9} \pm 3.1 \times 10^{8} \mathrm{IN} \mathrm{m}^{-2}$ at $115 \%$ relative humidity with respect to ice $\left(\mathrm{RH}_{\mathrm{ICE}}\right)$, and of $3.09 \times 10^{8} \pm 9.1 \times 10^{7} \mathrm{IN} \mathrm{m}^{-2}$ at $119 \% \mathrm{RH}_{\mathrm{ICE}}$ in FRIDGE. These data fit well into the observed dependence of $\xi$ on $\mathrm{RH}_{\mathrm{ICE}}$ (Fig. 9), which was obtained from field and laboratory measurements with the Colorado State University's Continuous Flow Diffusion Chamber (DeMott et al., 2003a, b; Archuleta et al., 2005) and recently compiled by Phillips et al. (2008). It is remarkable that this relation persists among data sets obtained with independent techniques and from very different atmospheric environments, such as Saharan dust over Florida (DeMott et al., 2003b) and Europe (this work), and background tropospheric air from Mt. Werner in the western US (DeMott et al., 2003a). This, and the proportionality of IN to aerosol surface add further evidence to support a key assumption of the parameterizations of heterogeneous ice nucleation, which is based on the singularity hypothesis of nucleation (Phillips et al., 2008). 

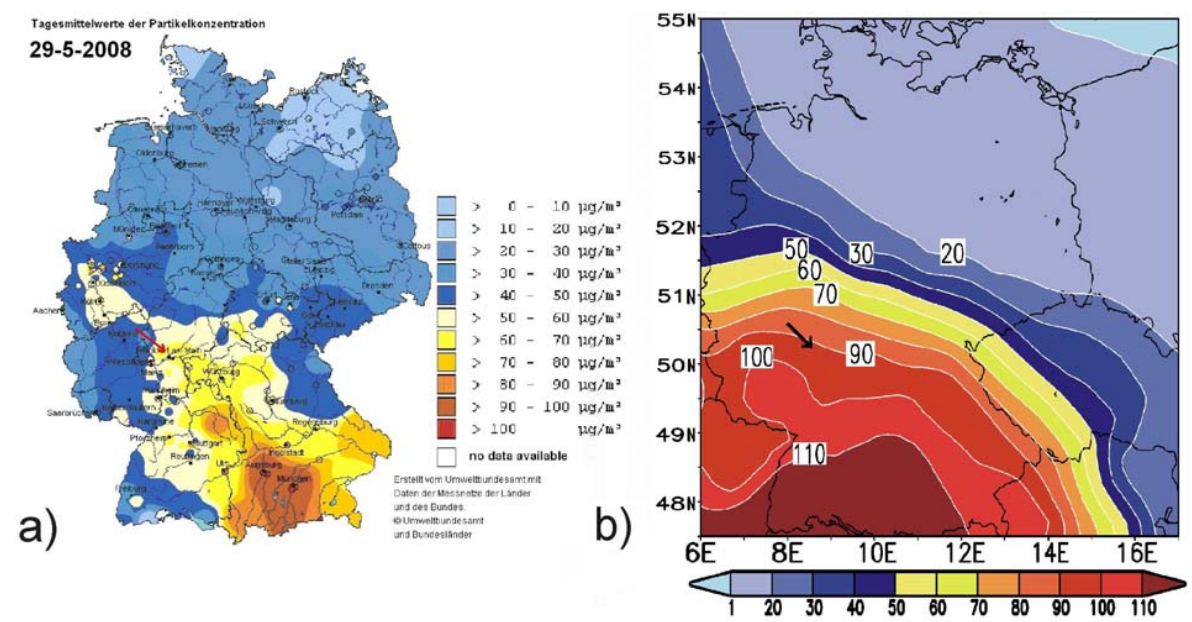

Fig. 5. Diurnal mean surface concentration by mass $\left(\mu \mathrm{g} / \mathrm{m}^{3}\right)$ of aerosol particles with diameter $<10 \mu \mathrm{m}$ (a) measured in Federal and statewide networks on 29 May 2008 in Germany, (@) data compiled by the German Federal Environment Agency, Umweltbundesamt); (b) simulated by DREAM model (size bins 1-7 in Table 1). (red and black arrows shows measurement-location Kleiner Feldberg).
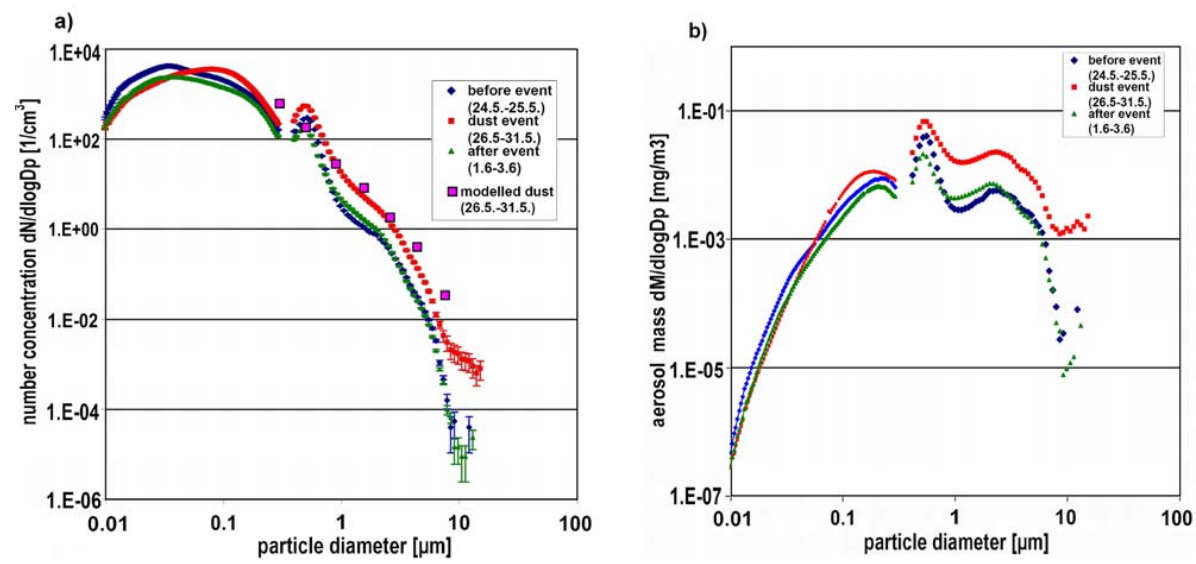

Fig. 6. Aerosol size spectra of number concentration (panel a) and mass concentration (panel b) measured at Taunus Observatory by scanning mobility particle sizer SMPS and aerodynamic particle sizer APS before (blue), during (red), and after (green) the dust event. Pink squares (panel a) denote the aerosol number concentration during the dust event as modelled by DREAM.

Third, the fraction of activated particles (i.e. number concentration of IN/number concentration of particles) during the days of peak dust load (28-30 May) is $4 . \pm 1.4 \times 10^{-4}$ (mean \pm std error of mean) based on APS-measurements of particles larger than $0.2 \mu \mathrm{m}$ diameter, and $3.7 \pm 8.3 \times 10^{-4}$ based on modelled concentrations of particles larger than $0.2 \mu \mathrm{m}$ diameter. This lies within the wide range of laboratory data on various Saharan dust aerosols analyzed at approximately the same nucleation conditions (Field et al., 2006; DeMott et al., 2010)

We note very little difference between the IN activation spectra (number of IN as a function of temperature and relative humidity) of the samples taken during the dust episode, and the average spectra from our one year record (Klein, 2010) at the Taunus Observatory (Fig. 10). For intercompar- ison these data are normalized with respect to the maximum number concentration $\mathrm{IN}_{\mathrm{MAX}}$ in each spectrum. IN $\mathrm{INAX}_{\mathrm{X}}$ is usually measured at the lowest temperature $\left(-18^{\circ} \mathrm{C}\right)$ and highest supersaturation $\left(\mathrm{RH}_{\mathrm{ICE}}=119 \%\right)$ in FRIDGE. Taking IN $\mathrm{NAX}_{\mathrm{X}}$ in each of the samples as $100 \%$, we find that in the dust samples $20-30 \%$ of $\mathrm{IN}_{\mathrm{MAX}}$ is activated at $97 \% \mathrm{RH}_{\mathrm{w}}$, and $15 \%$ at $93 \% \mathrm{RH}_{\mathrm{w}}$. In the annual mean $30 \%$ of $\mathrm{IN}_{\mathrm{MAX}}$ is activated at $97 \% \mathrm{RH}_{\mathrm{w}}$, and $20 \%$ at $93 \% \mathrm{RH}_{w}$. If one assumes that the different individual classes of materials (dust, soot, biogenic, ...) that may contribute to the IN throughout the year exhibit appreciably different slopes in their activation spectra in FRIDGE, then the massive presence of dust during the event of June 2008 could be expected to lead to spectra (Fig. 10a) that were different from those at the other times (Fig. 10b) and would thus result in a slope of the linear 


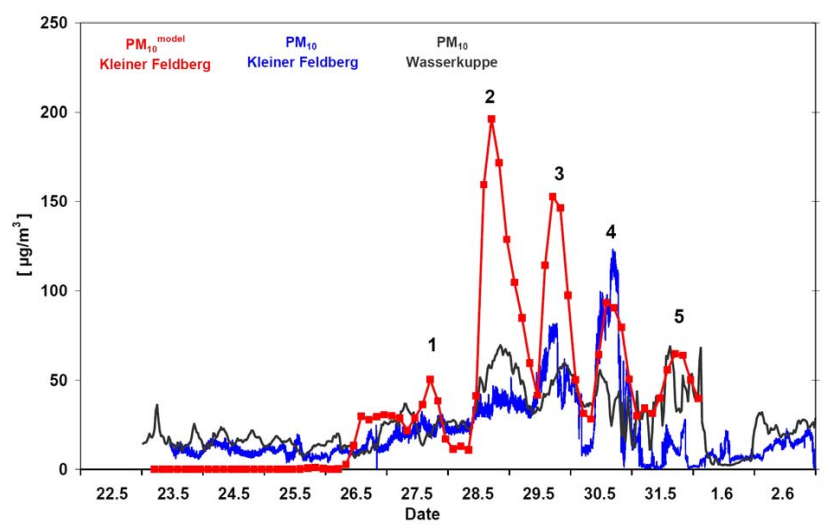

Fig. 7. Measured and modeled $\mathrm{PM}_{10}$ mass concentration during the dust event at the Taunus Observatory: blue curve: $\mathrm{PM}_{10}$ derived from APS size spectra of $d_{p}<10 \mu \mathrm{m}$; red cuve: $\mathrm{PM}_{10}$ calculated by DREAM model; black curve: $\mathrm{PM}_{10}$ measured at mountain weather station Wasserkuppe $110 \mathrm{~km}$ northeast of Observatory (HLUG 2008).

regression line between both data sets (Fig. 10c) that deviates from the 1:1 line. From the fact that our regression line lies within the $99.9 \%$ confidence bands of the $1: 1$ line one may conclude that the assumption above is invalid, and that the contribution of the different nucleating materials results in average spectra of the same slope as during the massive dust event, or that the properties and composition of the nucleating materials in both data sets were quite similar, and were likely made up to a large extent by mineral dust. Although the validity of our initial assumption cannot be proven because of unknown composition and properties of the nucleating material, we consider the latter explanation more likely. It is backed by observational data (Klein, 2010) showing that the abundance of IN at the Taunus Observatory throughout 2.5 years of daily measurement is highly correlated with local dust-specific parameters (e.g. extinction by large particles) derived from AERONET and satellite measurements.

Finally, the ESEM analysis of individual aerosol particles that was carried out on the substrates after processing by FRIDGE (see chapter 2) reveals that approximately $90 \%$ of the particles that acted as IN are silicates or Ca-carbonates (Table 3). According to Kandler et al. (2007) higher abundances of carbonates indicate source regions of the dust in the northern Sahara. In addition to the predominant silicate and carbonate particles, a few carbonaceous and metal oxide grains were observed as IN. The high abundance of mineral dust particles among IN observed in the present study is in good agreement with recent findings of Pratt et al. (2009). Based on in situ mass spectrometric measurements in an orographic wave cloud over Wyoming (at an altitude between 7.9 and $8.3 \mathrm{~km}$ above sea level) these authors observed an average relative number abundance of $50 \%$ for mineral dust in the fraction of particles acting as IN. However, in con- a)

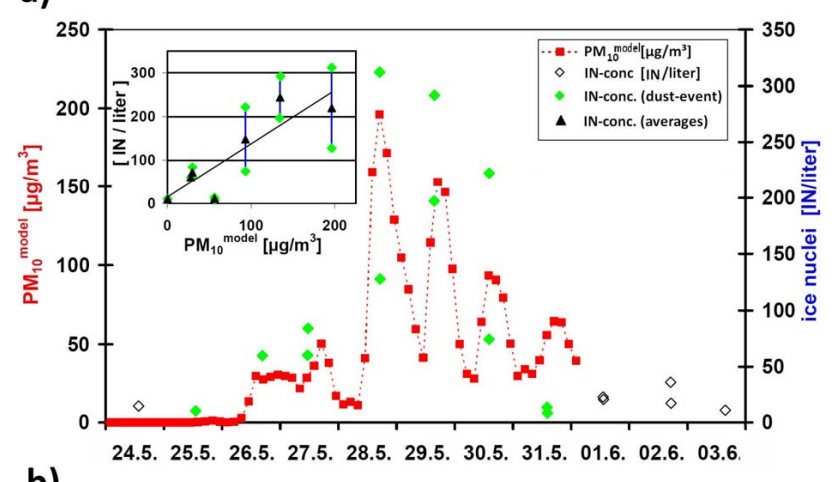

b)

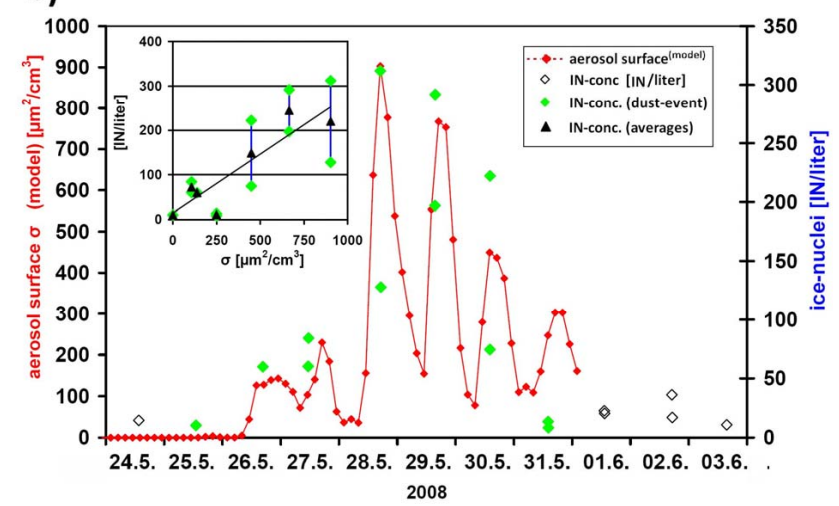

Fig. 8. (a) $\mathrm{PM}_{10}^{\text {model }}$ mass concentration at the Taunus Observatory calculated by the DREAM model and number concentration of ice nuclei (diamonds, \#/l, 18 samples) measured at Taunus Observatory as a function of time; Inset: Linear regression of IN number concentration during the dust event (triangles) against $\mathrm{PM}_{10}^{\text {model }}$ mass concentration: $\mathrm{y}[\mathrm{IN} / \mathrm{l}]=1.23 \cdot\left[\mathrm{PM}_{10}^{\text {model }}, \mu \mathrm{g} / \mathrm{m}^{3}\right]+14.76 ; R=0.888$. Triangles $(n=7)$ are means of those individual IN samples (green diamonds, $n=12$ ) which were taken within a period of one hour. (b) Same as (a) but for aerosol surface concentration $(\sigma)$ of model size bins 1-7. Inset: Linear regression of IN number concentration during the dust event (triangles) against $\mathrm{PM}_{10}^{\text {model }}$ surface concentration: $\mathrm{y}[\mathrm{IN} / \mathrm{l}]=0.26 \cdot \sigma\left[\mu \mathrm{m}^{2} / \mathrm{cm}^{3}\right]+14.80, R=0.919$. Triangles $(n=7)$ are means of individual IN samples (green diamonds, $n=12$ ) taken within a period of one hour.

trast to Pratt et al. (2009), we did not find biological particles acting as IN, although this particle group was found to be a major component at our sampling location in the size range of 1-30 $\mu \mathrm{m}$ (Ebert et al., 2004).

\section{Summary and conclusion}

The concentration of ice nuclei over Europe can be significantly affected by plumes of dust advected from the Sahara across large parts of the continent. Although the dust is transported mainly at several kilometers aloft, the surface concentration of ice nuclei and aerosol are dominated during such situations by dust. The surface concentration of ice 


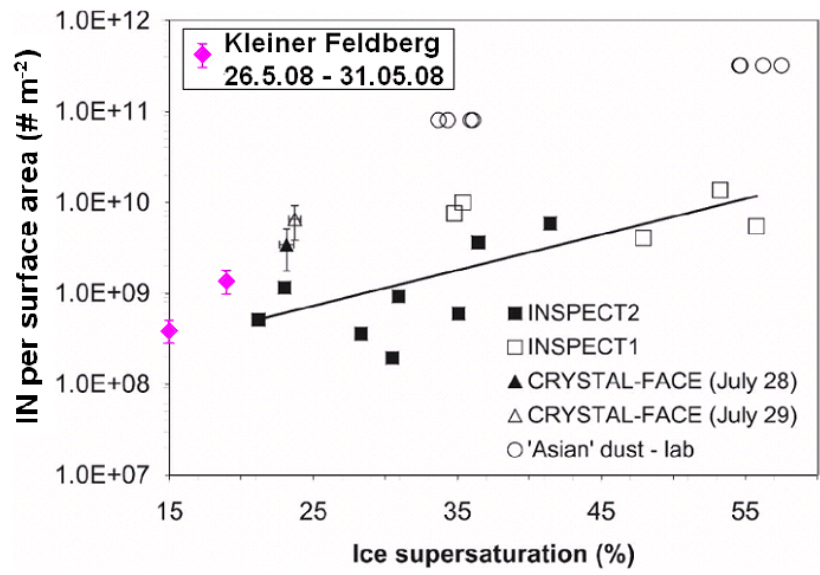

Fig. 9. Number of active ice nuclei per surface area of dust particles as function of supersaturation with respect to ice. Figure taken from Phillips et al. (2008), with data from this work (pink diamonds) added.
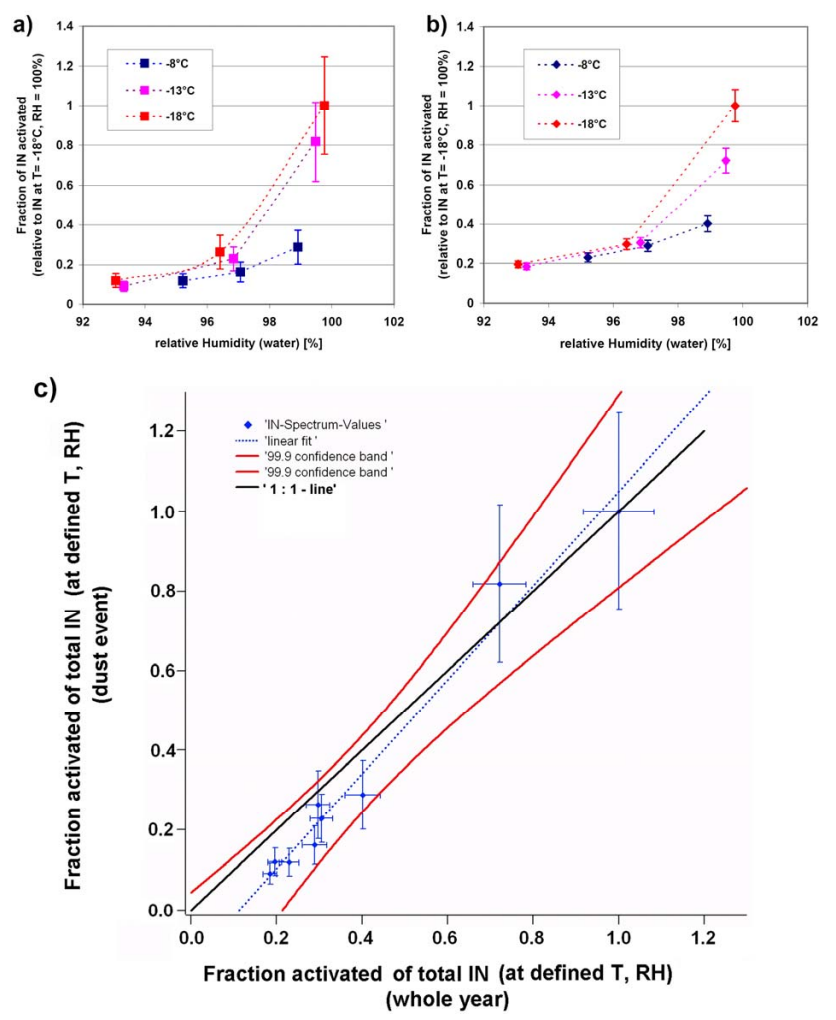

Fig. 10. Panel (a) fractional activation (\% of maximum) of IN as function of water saturation during the dust episode. Panel (b) same as in (a) but from 352 samples at the Taunus Observatory during 2008/09. Panel (c): scatter plot of data from (a) vs. data from (b).

nuclei closely resembled the plume structure derived by the DREAM dust transport model. The highest correlation of IN was to aerosol surface area. The fundamental assumption of nucleation schemes, that the number of active IN of a par-
Table 3. Relative number abundance [\%] of the different particle groups that acted as IN $(N=112)$.

\begin{tabular}{lll}
\hline particle group & mean value & $95 \%$ confidence interval \\
\hline silicates & 42.9 & $32.1-54.4$ \\
Ca-carbonates & 46.4 & $35.4-57.8$ \\
C-rich & 7.1 & $3.1-15.5$ \\
metal oxides & 3.6 & $1.1-10.7$ \\
\hline
\end{tabular}

* confidence intervals were calculated assuming a multinomial distribution.

ticular species of insoluble aerosol is approximately proportional to the total surface area of its aerosol particles (Phillips et al., 2008) is supported. The areal density of activated ice nuclei per aerosol surface as a function of the relative humidity over ice agrees well to the empirical relationship obtained by the Colorado State University's instrument. In the analysis by FRIDGE the ice nucleating characteristics of the aerosol sampled during the dust episode is similar to that of the aerosol during undisturbed conditions. We thus conclude that mineral dust may contribute significantly to the abundance and composition of IN in Central Europe during the whole year. This is supported by the observed correlation of IN to dust-specific parameters in a large data set from this site (Klein, 2010). Thus robust empirical relationships of IN to dust might in the future be used together with dust modelling as a first approach towards the prediction of IN for a given situation.

Acknowledgements. This work was financed by Deutsche Forschungsgemeinschaft (DFG) under the Collaborative Research Centre 641 and by the German Israeli Foundation for Scientific Research and Development (GIF). We thank the German Federal Environment Agency (Umweltbundesamt) for the permission to reproduce Fig. 5a, and the German Meteorological Service DWD for supplying the trajectories.

Edited by: D. Knopf

\section{References}

Ansmann, A., Mattis, I., Müller, D., Wandinger, U., Radlach, M., Althausen, D., and Damoah, R.: Ice formation in Saharan dust over central Europe observed with temperature/humidity/aerosol Raman lidar, J. Geophys. Res., 110(D18S12), doi:10.1029/2004JD005000, 2005.

Ansmann, M.,Tesche, M., Althausen, D., Müller, D., Seifert, P., Freudenthaler, V., Heese, B., Wiegner, M., Pisani, G., Knippertz, P., and Dubovik, O.: Influence of Saharan dust on cloud glaciation in southern Morocco during the Saharan Mineral Dust Experiment, J. Geophys. Res., 113, D04210, doi:10.1029/2007JD008785, 2008.

Archuleta, C. M., DeMott, P. J., and Kreidenweis, S. M.: Ice nucleation by surrogates for atmospheric mineral dust and mineral 
dust/sulfate particles at cirrus temperatures, Atmos. Chem. Phys., 5, 2617-2634, doi:10.5194/acp-5-2617-2005, 2005.

Barkan, J., Kutiel, H., Alpert, P., and Kishcha, P.: Synoptics of dust intrusion days from the African continent into the Atlantic Ocean, J. Geophys. Res., 109, D08201, doi:10.1029/2003JD004416, 2004.

Bertrand, J., Baudet, J., and Dessens, J.: Seasonal Variations and Frequency Distributions of Ice Nuclei Concentrations at Abidjan, West Africa, J. Appl. Meteorol. Soc. 1191-1195, 1973.

Bundke,U., Nillius, B., Jaenicke, R., Wetter, T., Klein, H., and Bingemer, H.: The Fast Ice Nucleus Chamber FINCH, Atmos. Res., 90, 180-186, doi:10.1016/j.atmosres.2008.02.008, 2008.

Choi, Y.-S., Lindzen, R. S., Ho, C.-H., and Kim, J.: Space observations of cold-cloud phase change, Proc. Natl. Acad. Sci. USA, 107, 11211-11216, 2010.

Collaud Coen, M., Weingartner, E., Schaub, D., Hueglin, C., Corrigan, C., Henning, S., et al.: Saharan dust events at the Jungfraujoch: detection by wavelength dependence of the single scattering albedo and first climatology analysis, Atmos. Chem. Phys., 4, 2465-2480, doi:10.5194/acp-4-2465-2004, 2004.

DeMott, P. J., Sassen, K., Poellot, M. R., Baumgardner, D., Rogers, D. C., Brooks, S. D., Prenni, A. J., and Kreidenweis, S. M.: African dust aerosols as atmospheric ice nuclei, Geophys. Res. Lett., 30(14), 1732, doi:10.1029/2003GL017410, $2003 \mathrm{a}$.

DeMott, P. J., Cziczo, D. J., Prenni, A. J., Murphy, D. M., Kreidenweis, S. M., Thomson, D. S., Borys, R., and Rogers, D. C.: Measurements of the concentration and composition of nuclei for cirrus formation, Proc. Natl. Acad. Sci. USA, 100, 1465514660, 2003b.

DeMott, P. J., Prenni, A. J., Liu, X., Kreidenweis, S. M., Petters, M. D., Twohy, C. H., Richardson, M. S., Eidhammer, T., and Rodgers, D. C.: Predicting global atmospheric ice nuclei distributions and their impacts on climate, Proc. Natl. Acad. Sci. USA, 107, 11217-11222, 2010.

DeMott, P. J., Möhler, O., Stetzer, O., Vali, G., Levin, Z., Petters, M. D., Murakami, M., Leisner, Th., Bundke, U., Klein, H., Z. Kanji, Z. A., Cotton, R., Jones, H., Benz, S., Brinkmann, M., Rzesanke, D., Saathoff, H., Nicolet, M., Saito, A., Nillius, B., Bingemer, H., Abbatt, J. P. D., Ardon, K., Ganor, E., Georgakopoulos, D. G., and Saunders, C.: Resurgence in ice nuclei measurement research, B. Am. Meteorol. Soc., submitted, 2010.

Di Iorio, T., di Sarra, A., Sferlazzo, D. M., Cacciani, M., Meloni, D., Monteleone, F., Fuà, D., and Fiocco, G.: Seasonal evolution of the tropospheric aerosol vertical profile in the central Mediterranean and role of desert dust, J. Geophys. Res., 114, D02201, doi:10.1029/2008JD010593, 2009.

Duce, R. A.: Sorces, distributions, and fluxes of mineral aerosola and their relatonship to climate, edited by:: Charlson, R. J. and Heintzenberg, J.: Aerosol forcing of climate, Wiley, Chichester, UK, 1995 .

Ebert M., Weinbruch S., Hoffmann P., and Ortner H. M.: The chemical composition and complex refractive index of rural and urban influenced aerosols determined by individual particle analysis, Atmospheric Environment 38, 6531-6545, 2004.

Ehrenberg, C. G.: Passatstaub und Blutregen, Abhandl. d. Kgl. Preuss. Akad. Wiss. Berlin aus dem Jahre 1847, 269-460, 1849.

Field, P. R., Möhler, O., Conolly, P., Krämer, M., Cotton, R., Heymsfield, A. J., Saathoff, H., and Schnaiter, M.: Some ice nucleation characteristics of Asian and Saharan desert dust, At- mos. Chem. Phys., 6, 2991-3006, doi:10.5194/acp-6-2991-2006, 2006.

Georgi, F.: A particle dry-deposition parameterization scheme for use in tracer transport models, J. Geophys. Res., 91, 9794-9806, 1986.

Hinds, W. C.: Aerosol Technology, John Wiley \& Sons Inc., New York, USA, 483 pp., 1998.

Hobbs, P. V., Bluhm, G. C., and Othake, T.: Transport of ice nuclei over the north pacific ocean, Tellus, 23, 28-39, 1971.

HLUG: Hessisches Landesamt fuer Umwelt und Geologie: data of air pollution monitoring: available online at: http://www.hlug. de/medien/luft/recherche/recherche.php?station=102), 2008.

HLUG: Hessisches Landesamt fuer Umwelt und Geologie: Lufthygienischer Monatsbericht Mai 2008, available online at: http://www.hlug.de/medien/luft/luftmessnetz/dokumente/2008/ mb_mai_08.pdf, 2008a.

Janjic, Z. I.: The Step-mountain Eta Coordinate Model: Further developments of the convection, viscous sublayer and turbulence closure schemes, Mon. Weather Rev., 122, 927-945, 1994.

IPCC: The Scientific Basis. A report of Working Group I of the Intergovernmental Panel on Climate Change, in: Climate Change 2007: The Physical Science Basis. Contribution of Working Group I to the Fourth Assessment Report of the Intergovernmental Panel on Climate Change, edited by: Solomon, S., Qin, D., Manning, M., Chen, Z., Marquis, M., Averyt, K. B., Tignor, M., Miller, H. L., Cambridge University Press, Cambridge, UK and New York, NY, USA, 996 pp., 2007.

Isono, K., Kombayasi, M., and Ono, A.: The nature and origin of ice nuclei in the atmosphere, J. Meteorol. Soc. Jpn., 37(6), 211232, 1959.

Kaminski, U.: Saharan dust observations at Hohenpeissenberg, in: The German Contribution to the WMO GAW Programme: Upon the $225^{\text {th }}$ Anniversary of GAW Hohenpeissenberg Observatory No. 167. Monitoring and Research of Climate, edited by: Fricke, W., Weather Environ. Change, WMO TD No. 1336, 80-83, 2006.

Kandler, K., Benker, N., Bundke, U., Cuevas, E., Ebert, M., Knippertz, P., Rodriguez, S., Schütz, L., and Weinbruch, S.: Chemical composition and complex refractive index of Saharan Mineral Dust at Izana, Tenerife (Spain) derived by electron microscopy, Atmospheric Environment, 41, 8058-8074, 2007.

Kaufmann, Y. J., Tanre, D., and Boucher, O.: A satellite view of aerosols in the climate system, Nature, 419, 215-223, 2002.

Klein, H.: Variabilität der Eiskeimkonzentration über Zentraleuropa (Variability of ice nucleus concentration over central Europe), PhD. Dissertation, University of Frankfurt, October 2010.

Klein, H., Haunold, W., Bundke, U., Nillius, B., Wetter, T., Schallenberg, S. and Bingemer, H.: A new method for sampling of atmospheric ice nuclei with subsequent analysis in a static diffusion chamber, Atmos. Res., 96, 218-224, 2010.

Klein, H., Bingemer, H., Herrmann, T., Weinbruch, S., Haunold, W., et al.: The seasonal variability of ice nuclei over Central Europe, in preparation, 2010a.

Knippertz, P. Ansmann, A., Althausen, D., Müller, D., Tesche, M., Bierwirth, E., Dinter, T.; Müller, T., Hoyningen-Huene, W., Schepanski, K., Wendisch, M., Heinold, B., Kandler, K., Petzold, A., Schütz, L. and Tegen, I.: Dust mobilization and transport in the northern Sahara during SAMUM 2006 - a meteorological overview. Tellus B, 61, 1, 12-31, available online at: 
http://dx.doi.org/10.1111/j.1600-0889.2008.00380.x, 2009.

Knopf, D. A. and Koop, T.: Heterogeneous nucleation of ice on surrogates of mineral dust, J. Geophys. Res., 11, D12201, doi:10.1029/2005JD006804, 2006.

Levin, Z. and Cotton, W. R. (Eds.): Aerosol pollution impact on precipitation, A scientific review, Springer, 386 pp., 2009.

Mattis, I., Müller, D., Ansmann, A., Wandinger, U., Preißler J., Seifert, P., and Tesche, M.: Ten years of multiwavelength Raman lidar observations of free-tropospheric aerosol layers over central Europe: Geometrical properties and annual cycle, J. Geophys. Res., 113, D20202, doi:10.1029/2007JD009636, 2008.

Murray, B. J., Wilson, T. W., Broadley, S. L., and Wills, R. H.: Heterogeneous freezing of water droplets containing kaolinite and montmorillonite particles, Atmos. Chem. Phys. Discuss., 10, 9695-9729, doi:10.5194/acpd-10-9695-2010, 2010.

Nickovic, S., Kallos, G., Papadopoulos, A., and Kakaliagou, O.: A model for prediction of desert dust cycle in the atmosphere, J. Geophys. Res., 106, 18113-18129, 2001.

Nickovic, S.: Dust Aerosol Modeling: Step Toward Integrated Environmental Forecasting, Eos. Trans. AGU, 83(47), Fall Meet., A71E-04, 2002.

Nickovic, S.: Distribution of dust mass over particle sizes: impacts on atmospheric optics, Forth ADEC Workshop - Aeolian Dust Experiment on Climate Impact, 26-28 January, Nagasaki, Japan, 357-360, 2005.

Niedermeier, D., S. Hartmann, R. A. Shaw, D. Covert, T. F. Mentel, J. Schneider, L. Poulain, P. Reitz, C. Spindler, T. Clauss, A. Kiselev, E. Hallbauer, H. Wex, K. Mildenberger, and Stratmann, F.: Heterogeneous freezing of droplets with immersed mineral dust particles - measurements and parameterization, Atmos. Chem. Phys., 10, 3601-3614, doi:10.5194/acp-10-3601-2010, 2010.

Papayannis, A., Amiridis, V., Mona, L., Tsaknakis, G., Balis, D., Bosenberg, J., Chaikovski, A., De Tomasi, F., Grigorov, I., Mattis, I., Mitev, V., Muller, D., Nickovic, S., Perez, C., Pietruczuk, A., Pisani, G., Ravetta, F., Rizi, V., Sicard, M., Trickl, T., Wiegner, M., Gerding, M., Mamouri, R. E., D’Amico, G., and Pappalardo, G.: Systematic lidar observations of Saharan dust over Europe in the frame of EARLINET (2000-2002), J. Geophys. Res., 113, D10204, doi:10.1029/2007JD009028, 2008.

Pérez, C., Nickovic, S., Pejanovic, G., Baldasano, J. M., and Özsoy, E.: Interactive dust-radiation modeling: A step to improve weather forecasts, J. Geophys. Res., 111, D16206, doi:10.1029/2005JD006717, 2006.

Phillips, V. T. J., DeMott, P. J., and Andronache, C.: An empirical parameterization of heterogeneous ice nucleation for multiple chemical species of aerosol, J. Atmos. Sci., 65, 2757-2783, 2008.

Pratt, K. A., DeMot, P. J., French, J. R., Wang, Z., Westphal, D. L., Heymsfield, A. J., Twohy, C. H., Prenni, A. J., and Prather, K. A.: In situ detection of biological particles in cloud ice-crystals, Nature Geoscience, 2, 398-401, 2009.

Prenni, A. J., Petters, M. D., Kreidenweis, S. M., Heald, C. L., Martin, S. T., Artaxo, P., Garland, R. M., Wollny, A. G., and Pöschl, U.: Relative roles of biogenic emissions and Saharan dust as ice nuclei in the Amazon basin, Nature Geoscience, 2, 402-405, 2009.
Prospero, J. M.: Long-range transport of mineral dust in the global atmosphere: Impact of African dust on the environment of the United States, Proc. Natl. Acad. Sci. USA, 96, 3396-3403, 1999.

Prospero, J. M., Ginoux, P., Torres, O., Nicholson, S. E., and Gill, T. E.: Environmental characterization of global sources of atmospheric soil dust identified with the NIMBUS 7 Total Ozone Mapping Spectrometer (TOMS) absorbing aerosol product, Rev. Geophys., 40, 1002, doi:10.1029/2000RG000095, 2002.

Pruppacher, H. R. and Klett, J. D.: Microphysics of Clouds and Precipitation, Reidel, Dordrecht, The Netherlands, 954 pp., 1997.

Sassen, K.: Indirect climate forcing over the western US from Asian dust storms, Geophy. Res. Lett., 29(10), 1465, 10.1029/2001GL014051, 2002.

Sassen,K., DeMott, P. J., Prospero, J. M., and Poellot, M. R.: Saharan dust storms and indirect aerosol effects on clouds: CRYSTAL-FACE results, Geophy. Res. Lett., 30(12), 1633, doi:10.1029/2003GL017371, 2003.

Schepanski, K., Tegen, I., Laurent, B., Heinold, B., and Macke, A.: A new Saharan dust source activation frequency map derived from MSG-SEVIRI IR-channels, Geophys. Res. Lett., 34, L18803, doi:10.1029/2007GL030168, 2007.

Tegen, I.: Modeling the mineral dust aerosol cycle in the climate system, Quart. Sci. Rev., 22, 1821-1834, 2003.

Tegen, I., and Fung I.: Modeling of mineral dust in the atmosphere: sources, transport, and optical thickness, , J. Geophys. Res., 99(D11), 22897-22914, 1994.

Tomadin, L.; Wagenbach, D. and Landuzzi, V.: Mineralogy and source of high altitude glacial deposits in the western Alps: clay minerals as Saharan dust tracers. In: Guerzoni, Stefano; Chester, Roy (Hg.): The impact of desert dust across the Mediterranean. Dordrecht, Boston, Kluwer Academic Publisher (Environmental science and technology library), 223-232, 1996.

Umweltbundesamt: Konzentrationen von $\mathrm{SO}_{2}, \mathrm{NO}_{2}, \mathrm{O} 3$ und $\mathrm{PM}_{10}$ aus dem Luftmessnetz des Umweltbundesamtes, Mai 2008, Berlin, 9 pp., 2008.

VDI (Verein Deutscher Ingenieure): Measurement of particulate precipitations. Sigma-2 sampler, VDI/DIN_Handbuch Reinhaltung der Luft, 4, 1-25, 1997.

Wiacek, A., Peter, T., and Lohmann, U.: The potential influence of Asian and African mineral dust on ice, mixed-phase and liquid water clouds, Atmos. Chem. Phys., 10, 8649-8667, doi:10.5194/acp-10-8649-2010, 2010.

Zeng, X., Tao, W., Zhang, M., Hou, A. Y., Xie, S., Lang, S., Li, X., Starr, D. O'C., Li, X., and Simpson, J.: An indirect effect of ice nuclei on atmospheric radiation, J. Atmos. Sci., 66, 41-61, 2009.

Zimmermann, F., Weinbruch, S., Schütz, L., Hofmann, H., Ebert, M., Kandler, K., and Worringen, A.: Ice nucleation properties of the most abundant mineral dust phases, J. Geophys. Res., 113, D23204, doi:10.1029/2008JD010655, 2008. 